\title{
Implementation of Creativity Learning in Arts Center Through Integrated Thematic Approaches to Stimulate the Discipline Character in TK Kreatif Makkah
}

\author{
Ernawita, ${ }^{1, *}$, Rakimahwati ${ }^{1}$ \\ ${ }^{1}$ Department of Early Childhood Education, Faculty of Education, Universitas Negeri Padang, Padang, Indonesia \\ *Email: ernawitarival@gmai.com
}

\begin{abstract}
This study aims to describe how the implementation of creativity learning in art center through an integrated thematic approach to stimulate the discipline character in the Makkah Creative Kindergarten Padang. The study was conducted from April to July 2019. The method used in the study was descriptive qualitative. The informants of this study were Fathonah class B teachers and Makkah Creative Kindergarten students, school principals and parents of students. Data collection techniques are observation, interviews and documentation and then the data are analyzed using Miles and Huberman analysis techniques by means of data reduction, data presentation and drawing conclusions from the data obtained during the study. Based on the results of the study it can be concluded that: (1) Learning Planning made by teachers in the creativity of arts center has used an integrated thematic while in the planting of discipline is not made planning that will be achieved on that day; (2) In the implementation of artistic center creativity learning through an integrated thematic approach by stimulating the cultivation of discipline there are findings that the implementation is good, (3) Student evaluation based on authentic assessment. It is recommended that teachers need to be given further training on how to implement artistic center creativity learning through an integrated thematic approach by stimulating the discipline character.
\end{abstract}

Keywords: early childhood creativity, arts center, integrated thematic, discipline

\section{INTRODUCTION}

The acceleration of information technology, especially in Early Childhood is a group of individuals aged between 0 8 years who are in a period of growth and development both physically and psychologically [1]. Early childhood education is one form of application of education that emphasizes the basic foundations towards growth, the development of physical coordination of soft and hard motor, and intelligence (mind, creativity, emotional intelligence, and spiritual intelligence [2].

Nowadays the potential of children in early childhood learning requires creativity as a support for the future success of children. Creativity is useful to equip children since preschool age with a variety of experiences and knowledge through a creative process, so as to achieve a better future and education, without one of the components of creativity, creativity will be lost or difficult to achieve. Early childhood creativity will lead to the 4P's component [3]. The development of early childhood creativity learning can be done by the teacher through the center which is a method that not only focuses on educators and learning material but is more constructive to the knowledge of students Arifin \& Fardana[4] in line with Rindaningsih[5] the subject of learning centers is children so that children can develop abilities in accordance with the potential it has, all learning is done while playing through the stimulation of children channeled to centers, including centers of role play, blocks, worship, arts of creativity, natural materials, preparation and exercise of Tatminingsih[6].

The creativity learning chosen in this research is learning in the arts center. The purpose of arts and creativity centers is to expand creative and skilled experiences in realizing ideas, ideas, and experiences [7]. The basic activities of early childhood art are various kinds of activities whose forms and manifestations are drama, dance, fine arts and music [8]. This research is focused on the implementation of the learning of fine arts creativity, namely drawing, painting with a brush, painting with fingers and hands, stamping, folding, tearing, glue and meronce [8]. For this art learning theme chosen is close to the child through an integrated thematic approach that is learning that instills the concept of knowledge of facts through interesting and close themes in the child's environment [9].

Furthermore, if the learning of artistic creativity is linked to the stimulation of the application of the discipline it will 
give character value to the child. Appropriate discipline planting is done from an early age because if the discipline behavior is formed to children from an early age it will become a valuable capital for children when they are adults [10]. Not all children's attitudes that reflect disciplinary behavior that is obedience to everyday rules and patience. Obedience to the rules is shown by the behavior of children who are willing to follow the rules consciously without coercion, are not angry when reminded by the rules of their friends, and remind their friends when they act improperly. Based on the above problems, this research is designed to find out how the implementation of creativity learning in art centers by stimulating the planting of discipline in early childhood in Creative Makkah Kindergarten Padang. Specifically there will be questions that will be answered in this study; (1) How to plan the learning of artistic creativity by stimulating discipline through integrated thematic in Makkah Creative Kindergarten; (2) How is the implementation of learning artistic creativity by stimulating discipline through integrated thematic in Makkah Creative Kindergarten; (3) How to evaluate the learning of artistic creativity by stimulating discipline through integrated thematic in Makkah Creative Kindergarten.

\section{METHOD}

This research method is qualitative research that intends to understand phenomena about what is experienced by research subjects such as behavior, perception, motivation, actions, etc. holistically and by means of descriptions in the form of words and language in a specific context that natural and by utilizing various natural methods [11]. Then according to Miles \& Huberman[12] qualitative research will bring up data in the form of words and not a series of numbers. The data may have been collected in various ways (observations, interviews, extracts, documents, tapes) and which are usually processed through recording, typing Data collection techniques are the most strategic step in research, because the main purpose of research is to get data [13]. In this research the writer will collect data with three kinds of techniques, namely: observation, interview and documentation study

Data validity is valid if it has four criteria according to what was revealed by Moleong[11], there are four kinds of data validity criteria namely credibility, tranferability, dependability, and certainty. While data analysis according to Miles \& Huberman[12], is data collection, data reduction, data presentation and drawing conclusions.

\section{DISCUSSION}

In the implementation of learning the teacher must be able to make learning plans according to the curriculum, this can be seen from the Kindergarten Creative Teachers making a weekly learning implementation plan (RPPM) selected at the creative arts center with the theme of the beauty of my country then the teacher makes a daily learning implementation plan (RPPH) with the theme specifically Minangkabau cuisine, a theme that is close to the child's environment. This fact is reinforced by the answers of the Makkah Creative Kindergarten school principal that the learning process begins with a theme developed by the teacher according to the needs of the child. In writing the lesson plan the teacher includes core competencies from K1 to $\mathrm{K} 2$ and Basic Competence but in the activity material the teacher only writes the material for creative arts activities and does not write the discipline activity material.

In implementing the creativity learning center of the teacher's art using the teacher's own playdogh material with food coloring that is safe to use for children with diverse colors so that children are more interested in making creations. The beginning of the implementation of learning centers began with a foothold before playing (praying and delivering material with an integrated thematic approach) then continued with a foothold playing (creating with playdogh making Minangkabau traditional food) then finally footing after playing (tidying playdogh materials, tables etc.). In the process of implementing the creativity of children's art centers, they make Minangkabau traditional food with their own creations so that their work has an element of authenticity of diverse works and ideas. According to one of the parents of the parents of Makkah Creative Kindergarten students, parents should develop children's creativity at home as much as possible through crayons, paper, natural materials and others. While in stimulating the inculcation of discipline the teacher reminds the child to discipline such as being on time, putting the material in its place, cooperating, helping and listening to what the teacher says and reinforced with the principal's response that to discuss child development, teachers and parents hold 1 x 2 meetings month.

While the evaluation or assessment stage, the teacher must conduct an authentic assessment of learning outcomes [15]. Makkah Creative Kindergarten teachers make an assessment for each child including daily assessments such as performance, work, anecdotes and then summarized with weekly, monthly and semester assessments. Based on observations made by researchers in the Makkah Creative Kindergarten in Fatonah Kindergarten B as many as 15 children using instruments that have been validated by experts Prof. Dr. Rakimahwati, M.Pd and Dr. Dadan Suryana with the percentage that children whose creativity develops very well (BSB) $13.3 \%$ discipline $1.8 \%$ while children whose creativity develops as expected (BSH) $61.8 \%$ discipline $76.1 \%$ then children whose creativity starts to develop ( MB) $8.2 \%$ discipline $6.64 \%$. Based on data analysis of the implementation of creativity learning arts centers by stimulating the cultivation of discipline through an integrated thematic approach that 


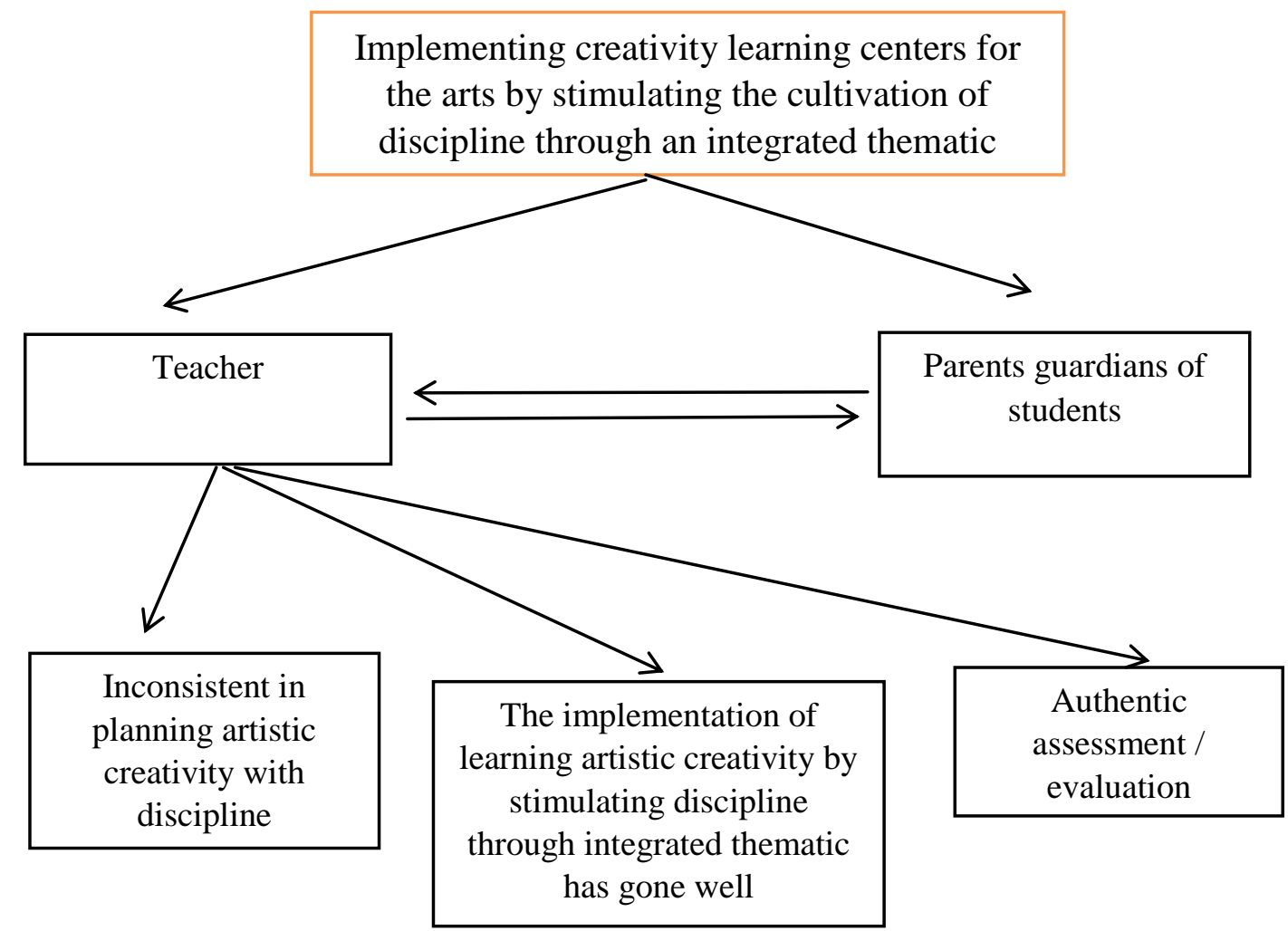

\section{CONCLUSIONS}

Based on the results of research and discussion that: (1) Planning creativity learning arts centers by stimulating the planting of discipline through an integrated thematic approach has not been consistent; (2) The implementation of learning about artistic creativity by stimulating discipline through integrated thematic works well; (3) Authentic assessment/evaluation.

\section{SUGGESTIONS}

It is recommended that teachers need to be given further training on how to implement artistic center creativity learning through an integrated thematic approach by stimulating the cultivation of discipline.

\section{REFERENCES}

[1] N. Y. Sujiono, Konsep Dasar Pendidikan Anak Usia Dini. Jakarta: Indeks, 2009.
[2] Rakimahwati, "Indonesian Journal of Early Childhood Character Development through Dance Learning in an Early Childhood Setting," vol. 3, no. 2, pp. 102-107, 2014.

[3] E. Dwirahmah, "Peningkatan Kreativitas melalui Pendekatan Inquiry dalam Pembelajaran Sains," $J$. Pendidik. USIA DINI, vol. 7, no. 1, 2013.

[4] A. K. Arifin and N. A. Fardana, "Peran Pendidik PAUD dalam Mengimplementasikan Pendidikan Karakter Melalui Metode Pembelajaran Sentra dan Lingkaran," J. Psikol. Pendidik. dan Perkemb., vol. 3, no. 3, 2014.

[5] I. Rindaningsih, "Pengembangan Model Manajemen Strategik Berbasis (Beyond Center and Circle Time) BBCT pada PAUD," PEDAGOGIA, vol. 1, no. 2, pp. 213-223, 2012.

[6] S. Tatminingsih, "Alternative Stimulasi Kemampuan Kognitif melalui Penerapan Model Pembelajaran Berbasis Permainan Komprehensif," J. Obs. J. Pendidik. Anak Usia Dini, vol. 3, no. 1, pp. 183-190, 2019.

[7] D. Wulandari, "Evaluasi Penerapaan Beyond Centers and Circle Time (BCCT) pada Pembelajaran Kelompok B di Tk An-Nuur Sleman," Universitas Negeri Yogyakarta, 2015. 
[8] Montolalu dkk, Bermain dan Permainan Anak. Jakarta: Universitas Terbuka, 2008.

[9] D. Suryana, "Pembelajaran Tematik Terpadu Berbasis Pendekatan Saintifik di Taman Kanak-kanak," $J$. Pendidik. Anak Usia Dini, vol. 11, no. 1, pp. 67-82, 2017.

[10] I. D. K. E. Dewi, N. K. Suarni, and M. Magta, "Penerapan Teknik Modeling untuk Meningkatkan Disiplin pada Anak Usia 5-6 Tahun," e-Journal Pendidik. Anak Usia Dini Univ. Pendidik. Ganesha, vol. 4, no. 3, 2017.

[11] L. J. Moleong, Metodologi Penelitian Kualitatif, Ketigapulu. Bandung: PT Remaja Rosdakarya, 2013.

[12] M. . Miles and A. . Huberman, Qualitative Data Analysis. London: Sage Publishers, 1994.

[13] Sugiyono, Metode Penelitian Kuantitatif, Kualitatif dan R\&D, 15th ed. Bandung: Alfabeta, 2012.

[14] M. B. Miles and A. M. Huberman, Qualitative Data Analysis: A Sourcebook of New Methods. London: Sage Publications, 1987.

[15] I. Arifin, Kepemimpinan PAUD Menerapkan Pusat Studi Kasus Persiapan Nasional Paud/Kb Anak Saleh Malang. Yogyakarta: Aditya Media, 2009. 